\title{
CLIMATE CHANGE IMPACT ON POPULATION DENSITY OF PARLATORIA DATE SCALE INSECT, PARLATORIA BLANCHARDII INFESTING DATE PALM TREES IN LUXOR GOVERNORATE, EGYPT
}

\author{
BAKRY, M.M.S. ${ }^{1}$, M.A.A. ABDRABBO ${ }^{2}$ and A.M.A. SALMAN ${ }^{3}$
}

1. Scale insects and Mealybugs Research Dept., Plant Protection Research Institute, ARC, Dokii, Giza, Egypt.

2. Central laboratory for Agricultural Climate (CLAC), ARC, Giza- Egypt

3. Plant Protection Dept., Fact. Agric. Sohag Univ., Sohag, Egypt.

1md.md sabry@yahoo.com

(Manuscript received $3^{\text {rd }}$ November 2014)

\begin{abstract}
$\mathrm{T}$ he present work was carried out to study the effect of climate change on the population density of the parlatoria date scale, $P$. blanchardii on date palm trees during the current (2009 to 2013) years and climate change conditions (2050 and 2100 years) at Esna district, Luxor Governorate. In order to compare the population density of pest under current data (average from 2009 to 2013 years) and future conditions, collected data was used to generate climate data under climatic changes conditions. The future climatic data values of (2050 and 2100 years) were used to predict the population density of $P$. blanchardii under climate change individually. Two climate change scenarios (A1 and B1) were used to assess the consequences of climate change on population density of pest on date palm trees under 2050 and 2100 years. The obtained results showed that monthly observations of total population of $P$. blanchardii had three to four peaks of seasonal activity per year. Also, the population density of insect increased in 2050s and 2100s as compared to base year data (average from 2009 to 2013 years). The percentages of explained variance (E.V.) indicate that the temperature was responsible for $70.7,66.2$ and $69.45 \%$ of the population changes of nymphs, adult numbers and total population of insect during the current year's data, respectively. Expected total population of insect will be higher at 2100s than expected through the 2050s under the two scenarios (A1 and B1). Furthermore, scenario A1 (worst case) is higher in numbers of nymphs, adult females and total population of $P$. blanchardii as compared with B1 scenario (best case). Also, scenario A1 at 2100s will gave the highest total population of insect and scenario B1 at 2050s gave the lowest one. The results showed that the increased temperatures during $2050 \mathrm{~s}$ and 2100s will increase the seasonal activity of $P$. blanchardii in Luxor Governorate, Egypt. Generally, the population density of $P$. blanchardii increased depending on climate region and climate change Scenarios.

Key words: DPS, Parlatoria date scale, Parlatoria blanchardii, seasonal activity, temperature, climate change scenarios and date palm trees.
\end{abstract}




\section{INTRODUCTION}

Among several pests, infesting date palm trees (Phoenix dactylifera L.), parlatoria date scale insect, Parlatoria blanchardi (Targioni-Tozzetti) is considered one of the most destructive pests. Adults and nymphs of this insect feed on leaves sap, sucking great amount of sap which contain macro- and micro-elements. At high level of infestation with this scale insect, remarkable damage occurs, resulting in early leaves drop and yield reduction (El-Said, 2000). Great damages can be done by this scale insect by sucking the plant sap that give low rates of photosynthesis and respiration which leads to curling, yellowing and dropping to leaves. The subsequent damage leads to considerable quality and quantity yield losses and also marketing value of the fruits. A characteristic symptom of infestation by $P$. blanchardii is the appearance and accumulation of its scales on attacked palm parts (El-Said, 2000, ElSherif et al., 2001 and Blumberg, 2008).

To develop an effective control against DPS, it is essential to know its bioecology including population dynamics and climatic factors influencing the life history and the densities of different phonological stages. Temperature has a direct influence on insect activity and rate of development. According to Zalom and Wilson (1982) the rate of development is based on the accumulation of heat measured in physiological rather than chronological time. Dent (1991) stated that the seasonal phenology of insect numbers, the number of generations, and the level of insect abundance at any location are influenced by the environmental factors at that location. Among IdderIghili et al. (2015) findings, adult females of date palm scale (DPS) were the most affected by climate factors. For the total DPS population, high values of minimum temperatures negatively affected population density, while high max. temps. showed a positive influence. In Egypt, the pest has two annual generations in spring and autumn (Abdel-Kareim and Awadalla, 1998).

Climate change has become one of the major challenges for mankind and the natural environment. Climate change related factors like rise in temperature and increased incidence of extreme weather events can directly influence insects by affecting their rate of development, reproduction, distribution, migration and adaptation. In addition, indirect effects can occur through the influence of climate on the insect's host plants, natural enemies and interspecific interactions with other insects (Salem and Hamdy, 1985, Bale et al., 2002, Walther et al., 2002, Samways, 2005 and Merrill, 2008).

Increment in temperature associated with climatic change would effect crop pest insect populations in several complex ways like (a) extension of geographical 
range (b) increased over-wintering (c) changes in population growth rate (d) increased number of generations (e) extension of development season (f) changes in crop pest synchrony $(\mathrm{g})$ changes in interspecific interactions $(\mathrm{h})$ increased risks of invasions by migrant pests and (i) introduction of alternative hosts and over-wintering hosts. But all these effects of temperature on insects largely overwhelm the effects of other environmental factors (Bale et al., 2002 and Menéndez, 2007).

The assessment report from the Inter-governmental Panel on Climate Change (IPCC) predicts an increment in mean temperature from 1.1 to $5.4^{\circ} \mathrm{C}$ toward the year 2100 (Meehl et al. 2007). An increment of this magnitude is expected to affect global agriculture significantly (Cannon, 1998). In addition, such changes in climatic conditions could profoundly affect the population dynamics and the status of insect pests of crops (Woiwod, 1997). These effects could either be direct, through the influence that weather may have on the insects physiology and behavior (Parmesan, 2007 and Merrill et al. 2008), or may be mediated by host plants, competitors or natural enemies (Bale et al. 2002).

The objective of this study is to predict the populations of the parlatoria date scale, P. blanchardii during 2050 and 2100 years compared with the current population of pest (average of population density from 2009 to 2013 years). As well as, the different effects of temperature on pest population from 2009 to 2013 years.

\section{MATERIALS AND METHODS}

The population fluctuations of parlatoria date scale (PDS) which infest date palm trees were carried out at half-monthly intervals at Esna district, Luxor Governorate during five successive years (from 2009 to 2013 years). An orchard about one feddan was selected for sampling during the studied period. Ten palm trees of White variety of almost similar and as uniform as possible in size, age ( 5 years), shape, height, vegetative growth were selected. These palm trees were left without pruning the fronds as well as they were not exposed for any chemical control measures before and during the period of investigation and randomly chosen for sampling at half-monthly intervals to conduct the study. The sample size (10 leaflets) was taken from different directions and levels of palm trees. The samples were collected regularly and immediately transferred to laboratory in polyethylene bags for inspection using a stereo-microscope. Numbers of alive insects on upper and lower surfaces of date palm trees leaflets were individually sorted into immature stages (nymphs) and mature stages (adult females) and then were counted and recorded together opposite to each inspected date. 
Monthly mean numbers of $P$. blanchardii per date palm leaflet from 2009 to 2013 years was considered in this study as current population of pest. The halfmonthly of maximum and minimum air temperatures at Luxor governorate from 2009 to 2013 years were obtained from the Central Laboratory for Agricultural Climate, Agriculture Research Center, Ministry of Agriculture in Giza. The altitude, latitude and longitude of this weather region of Luxor were $99 \mathrm{~m}, 25.67{ }^{\circ} \mathrm{N}$ and $32.71^{\circ} \mathrm{E}$, respectively.

\section{Climate change scenarios:}

The climate change data were conducted by MAGICC/SCENGEN tool to extract the projection changes in air temperature ( $\triangle$ air-temp) under the two IPCC's SRES scenarios (A1 and B1) that are described in Table (1). HadCM3 climate model was the base model under the two experiments. Each experiment extracted monthly $\Delta$ air-temp, for one of the two scenarios, for the coming years 2050s and 2100s. The resulted data from MAGICC/SCENGEN were in $5^{\circ} \times 5^{\circ}$ coordination grid. The future $\Delta$ air temp., data were downscaled by simple statistical approach, according to the Egyptian coordinates, and added to the historical air temperature data, to produce the future temperature data.

- Current climate condition: (Average of temperature from 2009 to 2013 years).

- Future climatic conditions: (in 2050 and 2100 years under A1 and B1 scenarios).

- Current population density: (Average of population density from 2009 to 2013 years).

Statistical analysis in the present work was carried out with Computer using (MSTATC Program software, 1980). The data obtained were statistically analyzed by using regression model are based on polynomial relationship between dependent variable (numbers of insect) and independent variable (temperature). The t-test was used to establish whether a significant difference exists between the current insect population (average from 2009 to 2013 years) and the estimated populations of 2050 and 2100 at $P \leq 0.05$.

Table 1. Description of IPCC Special Report on Emissions Scenarios (SRES):

\begin{tabular}{|c|l|}
\hline Scenario & \multicolumn{1}{|c|}{ Storylines } \\
\hline A1 & $\begin{array}{l}\text { Rapid economic growth, low population growth, rapid adoption of new technologies, } \\
\text { convergence of regions, capacity building, increased social interaction, reduced region } \\
\text { differences in per capita income. } \\
\text { Temperature increased } 1.4-6.4^{\circ} \mathrm{C}\end{array}$ \\
\hline B1 & $\begin{array}{l}\text { Convergent world with low population growth, transition to service and info economy, } \\
\text { resource productivity improvements, clean technology towards global solutions. } \\
\text { Temperature increased } 1.1-2.9^{\circ} \mathrm{C}\end{array}$ \\
\hline
\end{tabular}




\section{RESULTS AND DISCUSSION}

\section{1- The means of the monthly air temperature in Luxor region:}

\section{1- Trend of air temperature from 2009 to 2013 years:}

The means of the monthly air temperature were recorded from January, 2009 till December, 2013 (Fig., 1). The highest monthly mean air temperature values were recorded during the summer months (June, July and August) during all studied years. While, the winter months (December, January and February) had the lowest values of temperature.

The highest average annual air temperature value $\left(27.91^{\circ} \mathrm{C}\right)$ was recorded at 2013, followed by 2011, 2012 and 2010 years (25.66, 25.02 and 23.99 $\left.{ }^{\circ} \mathrm{C}\right)$, respectively. Whereas, the lowest average air temperature was recorded in 2009 year $\left(22.88^{\circ} \mathrm{C}\right)$.

\section{2- Trend of air temperature current and future conditions:}

Fig. (2), shows the average monthly trend of the mean air temperature under current climate (average of temperature from 2009 to 2013 years) and future conditions (2050 and 2100 years). The highest monthly mean air temperature values were recorded in July, while the lowest recorded during January for the current and predicted data.

Regarding, the predicted average air temperature in Luxor Governorate, the highest average air temperature was found under A1 scenario in most months, while the lowest was found under $\mathrm{B} 1$ scenario. The means of temperature degrees was $25.1^{\circ} \mathrm{C}, 28.3^{\circ} \mathrm{C}, 30.4^{\circ} \mathrm{C}, 27.7^{\circ} \mathrm{C}$ and $29.1^{\circ} \mathrm{C}$ as a general average of year were recorded in the current climate, 2050s A1, 2100s A1, 2050s B1 and 2100s B1, respectively.

The average differences of annual mean air temperature under current climate and $2050 \mathrm{~s}$ ranged between $2.6^{\circ} \mathrm{C}$ under $\mathrm{B} 1$ scenario to $3.2^{\circ} \mathrm{C}$ under $\mathrm{A} 1$ scenario. For 2050s, the lowest average air temperature was found under B1 scenario. While, the differences of air temperature under current and 2100 s data were ranged between $4.0^{\circ} \mathrm{C}$ under $\mathrm{B} 1$ scenario to $5.3^{\circ} \mathrm{C}$ under $\mathrm{A} 1$ scenario (Fig. 2). This result was agreeable with IPCC (2007) which reported that the highest average monthly air temperature values were under $A 1$ scenario in comparison with the other scenarios (A2, B1 and B2) during the most months of the years of (2050 and 2100) was found in the Upper Egypt region.

According to previous results, A1 considered as the "worst case" of airtemperature while, B1 was considered as the "best case". IPCC (2006) which mentioned that temperature will increase by uneven values in different climatic regions under climate change conditions. Moreover, climate changes may be have important impacts on agriculture. Based on the simulation of GCMS, future changes of 
global average temperature are expected to be between $2.8^{\circ} \mathrm{C}$ and $4.5^{\circ} \mathrm{C}$ in this century (IPCC, 2001), and some regional areas would be even warmer than the global average (Giorgi and $\mathrm{Bi}, 2005$ ).

\section{2-Seasonal fluctuations in population of $P$. blanchardif:}

\section{1- Immature stages (nymphs):}

The monthly mean number of nymphs of $P$. blanchardii on date palm leaflets at Esna district, Luxor Governorate during the period from 2009 to 2013 years and current population are graphically illustrated in Fig. (3).

The results showed that the nymphs of insect had four peaks per year, in April, June, September and November in all studied years and current population expect, 2009 year, the nymphs of insect had three peaks per year, which was recorded in April, June and October, Fig. (3).

\section{2- Mature stages (adult females):}

A similar trend in the seasonal fluctuation of adult females of $P$. blanchardii was observed, with different values. The adult females had four peaks that were recorded in April, June, September and November in all studied years and current population, Fig. (4).

\section{3- Total population of $\boldsymbol{P}$. blanchardif:}

According to data of total population of insect, four peaks were recorded in April, June, September and November in all studied years and current population expect, 2009 year, the total population of insect had three peaks per year, which was recorded in April, June and October, Fig. (5).

Most authors indicated three or four peaks per year for $P$. blanchardii depending on the area, environmental conditions and the host plant world wide. Hussain (1996) at Bahria Oases, Egypt, stated that the population density of $P$. blanchardii on date palms had three peaks in October, March and July. Youssef (2002) at Baltim region, Kafr El- Sheikh Governorate, Egypt, reported that this insect had three peaks during the year, the highest peak was found in October, the second in March and the smallest third one in June. But, Eraki (1998), El-Said (2000), El-Sherif et al. (2001) and Elwan and El-Said (2009) in Egypt, they reported that the $P$. blanchardii had four peaks per year.

\section{3- Relationship between mean temperature and the population density of different stages of $\boldsymbol{P}$, blanchardifi:}

\section{1- Effect of mean temperature on the population density of nymphs:}

When the data on mean monthly temperature from 2009 to 2013 years were regressed against the nymph numbers of $P$. blanchardii, a polynomial relationship was obtained between them is illustrated in Fig. (6). The equations as follows:

$Y=0.0262 x^{3}-1.7481 x^{2}+38.731 x-233.5 \quad R^{2}=0.643$ for 2009 year 
$Y=0.0485 x^{3}-3.857 x^{2}+99.196 x-746.72 \quad R^{2}=0.589$ for 2010 year

$Y=0.0091 x^{3}-0.8157 x^{2}+25.209 x-190.95 \quad R^{2}=0.634$ for 2011 year

$Y=0.018 x^{3}-1.5103 x^{2}+43.234 x-336.27 \quad R^{2}=0.581$ for 2012 year

$Y=0.0234 x^{3}-2.104 x^{2}+63.398 x-533.23 \quad R^{2}=0.609$ for 2013 year

The means of population densities data of nymphs and temperature degrees for five years (from 2009 to 2013) was used as the current data and study of the relationship between them is illustrated in Fig. (6).

The used equation was as follows:

$Y=0.0259 x^{3}-2.0909 x^{2}+56.268 x-424.43 R^{2}=0.71$ for current data

Where: $(Y)$ was the predicted nymph numbers of $P$. blanchardii and $(X)$ was the mean temperature.

The relationship gave a good fit to the data and the coefficient of determination were $\mathrm{R}^{2}=0.707$ for current data. $\mathrm{R}^{2}$ showed that the increase in nymph numbers of $P$. blanchardii occurred due to the increase in mean monthly temperature.

\section{2- Effect of mean temperature on the population density of adult females numbers:}

When the adult female's numbers of $P$. blanchardii were linked to the data of mean monthly temperature from 2009 to 2013 years, a polynomial relationship was obtained in Fig. (7). The equations as follows:

$$
\begin{array}{ll}
Y=0.0069 x^{3}-0.5014 x^{2}+12.991 x-68.632 & R^{2}=0.658 \text { for } 2009 \\
Y=0.0264 x^{3}-1.9934 x^{2}+49.522 x-350.78 & R^{2}=0.6426 \text { for } 2010 \\
Y=0.0129 x^{3}-1.063 x^{2}+29.143 x-202.33 & R^{2}=0.6071 \text { for } 2011 \\
Y=0.029 x^{3}-2.2791 x^{2}+58.999 x-443.03 & R^{2}=0.6421 \text { for } 2012 \\
Y=0.0253 x^{3}-2.2131 x^{2}+63.47 x-516.7 & R^{2}=0.653 \text { for } 2013
\end{array}
$$

The average of five years for each of the adult female's numbers and the temperature, a polynomial relationship between them represented in Fig. (7). The used equation was as follows:

$$
Y=0.0202 x^{3}-1.6 x^{2}+41.9 x-301.48 R^{2}=0.6616 \text { for current data }
$$

Where: $(Y)$ was the predicted adult numbers of $P$. blanchardii and $(X)$ was the mean temperature. This result indicates that the increase in adult numbers of $P$. blanchardii happened due to the increase in mean monthly temperature. The fitness of equation

reflects the existence of high significance of relationship were $R^{2}=0.662$ for current data.

\section{3- Effect of mean temperature on the population density of total population of $\boldsymbol{P}$. blanchardit:}

When the total population of $P$. blanchardii was related to the data of mean monthly temperature from 2009 to 2013 years, a polynomial relationship was obtained in Fig. (8). 
The equations as follows:

$$
\begin{array}{ll}
Y=0.0331 x^{3}-2.2495 x^{2}+51.722 x-302.13 & R^{2}=0.7857 \text { for } 2009 \\
Y=0.0749 x^{3}-5.8504 x^{2}+148.72 x-1097.5 & R^{2}=0.6102 \text { for } 2010 \\
Y=0.0221 x^{3}-1.8787 x^{2}+54.352 x-393.28 & R^{2}=0.6325 \text { for } 2011 \\
Y=0.047 x^{3}-3.7894 x^{2}+102.23 x-779.29 & R^{2}=0.602 \text { for } 2012 \\
Y=0.0487 x^{3}-4.3171 x^{2}+126.87 x-1049.9 & R^{2}=0.6278 \text { for } 2013
\end{array}
$$

The average of five years for each of the total population of insect and temperature, exactly a polynomial relationship between them represented in Fig. (8).

The used equation was as follows:

$Y=0.0461 x^{3}-3.691 x^{2}+98.169 x-725.91 R^{2}=0.6945$ for current data

Where: $(\mathrm{Y})$ was the predicted total population of $P$. blanchardii and $(X)$ was the mean temperature. This result indicates that the increase in total population of $P$. blanchardii take place due to the increase in mean monthly temperature, Fig. (8). The relationship gave a good fit to the data and the coefficient of determination were $\mathrm{R}^{2}=$ 0.6945 for current data. The amount of variability that could be attributed to the effect of mean monthly temperature on total population of insect was $69.45 \%$.

Generally, the percentages of explained variance (E.V.) indicate that the temperature was responsible for $70.7,66.2$ and $69.45 \%$ of the population changes of nymphs, adult numbers and total population of insect during the current year data, respectively.

These results were coincided with those obtained by Laudeho and Benassy (1969) in Mauritania, stated that the density and severity of infestation with $P$. blanchardii is affected by microclimate conditions. High temperature combined with wind and low humidity was very effective for the survival of the crawlers. El-Said (2000) in North Sinai, Egypt, stated that the effect of day maximum temperature was highly significant positive in the first year and insignificant negative in the second year of experiment.

\section{Estimated the population density of different stages of $\boldsymbol{P}$. blanchardii under the two different climate change scenarios (A1 and B1). \\ 4.1- Numbers of nymphs:}

According to equation of current data (average for population density from 2009 to 2013 years for nymphs) and monthly mean temperature under climate change scenarios (A1 and B1) for 2050s and 2100s we can estimate nymph numbers for $P$. blanchardii. Data in Table (1), showed that the increase between nymph numbers in the current data and 2050s under A1 scenario with an average yearly increase was $21.23 \%$ and the increase between the current data and 2100 s with an average yearly increase was $39.19 \%$.

Scenario B1 had the same trend. The increase of nymph numbers in the current data and 2050s with an average yearly increase was $17.20 \%$, while the 
increase between current data and $2100 \mathrm{~s}$ with an average yearly increase was $28.99 \%$. There were significance differences between actual current nymph numbers and estimated nymphs numbers in 2050s, 2100s under A1 and B1 scenario.

Results indicated also that, the nymph numbers increased under climate change scenarios, the highest population density of nymphs was recorded at $2100 \mathrm{~s}$ compared to 2050s under the two scenarios (A1 and B1).

\section{2- Numbers of adult females:}

Based on the equation of basic data (average for population density from 2009 to 2013 years for adult females) and monthly mean temperature under climate change scenarios (A1 and B1) for 2050s and 2100s we can estimate adult females numbers for $P$. blanchardii.

Data in Table (2), showed that the increase of adult females between the current data and 2050s under A1 scenario with an average yearly increase was $18.10 \%$ and the increase between the current data and 2100 s with an average yearly increase was $35.22 \%$.

Scenario B1 had the same trend of the increase of adult females numbers between the current data and 2050s with an average yearly increase was $14.49 \%$, while the increase between current data and 2100s with an average yearly increase was $25.53 \%$. There were significance differences between basic current adult females numbers and estimated adult females numbers in 2050s, 2100s under scenarios A1 and B1.

The obtained results showed that, the number of adult females in 2050s was less than that recorded in 2100 s under the two tested scenarios (A1 and B1).

\section{3- Numbers of total population of $\boldsymbol{P}$. blanchardii:}

Confirmed to equation of basic current data (average for population density from 2009 to 2013 years for total population) and monthly mean temperature under climate change Scenario (A1 and B1) for 2050s and 2100s we can estimate total population numbers of $P$. blanchardii.

Data in Table (3), showed that the increased between total population numbers in the current data and 2050s under A1 scenario with an average yearly increase was $19.86 \%$ and the increase between the current data and 2100 s with an average yearly increase was $37.45 \%$.

Scenario B1 had the same trend. The increase of total population numbers in the current data and 2050s with an average yearly increase was $16.02 \%$, while the increase between current data and 2100 s with an average yearly increase was $27.47 \%$. There were significance differences between actual current total population numbers and estimated nymphs numbers in 2050s, 2100s under A1 and B1 scenarios.

Results here agree with the concepts of the following literatures ex. Climate change has been recognized globally as the most impending and pressing critical issue 
affecting mankind survival in the $21^{\text {st }}$ century. The last assessment report from the Intergovernmental Panel on Climate Change predicted an increment in mean temperature from $1.1-6.4^{\circ} \mathrm{C}$ by 2100 (IPCC, 2007).

From the previously mentioned results, it could be concluded that the total population of insect was higher at 2100 year as compared with the 2050 year under the two scenarios (A1 and B1). Furthermore, scenario A1 (worst case) gave the highest numbers of nymphs, adult females and total population of $P$. blanchardii as compared with scenario B1 (best case).

Generally, scenario $A 1$ at 2100 s gave the highest total population of $P$. blanchardii and scenario B1 at 2050s gave the lowest one.

These results are almost in agreement with those of Farag et al. (2013), who studied the prediction of the populations of citrus wax scale, Ceroplastes floridensis during 2050 and 2100 years compared with the pest populations of 2012 year as well as the different effect of temperature on populations of 2000 and 2012 years Using the Two IPCC's SRES Scenarios (A2 and B2) in Sharkia Governorate. They reported that the increased in nymph numbers in $2012 \& 2050$ years and $2012 \& 2100$ years under $A 2$, with average yearly increased, were $20.4 \%$ and $60.0 \%$, respectively. While, under B2 were $23.1 \%$ and $42.6 \%$, respectively. Estimated adult numbers for $C$. floridensis under the two different climate change Scenario (A2 and B2). The results showed that the increased between Adult numbers in 2012 \& 2050 years and 2012 \& 2100 years under A2 with average yearly increased were $32.6 \%$ and $103.0 \%$, respectively. While under B2 were $37.9 \%$ and $72.5 \%$, respectively.

\section{CONCLUSION}

The aforementioned results revealed that the increased temperatures during 2050 and 2100 will increase the population activity of $P$. blanchardii in Luxor Governorate, Egypt. The increment in population density of $P$. blanchardii is depending on climate region and climate change Scenarios. 


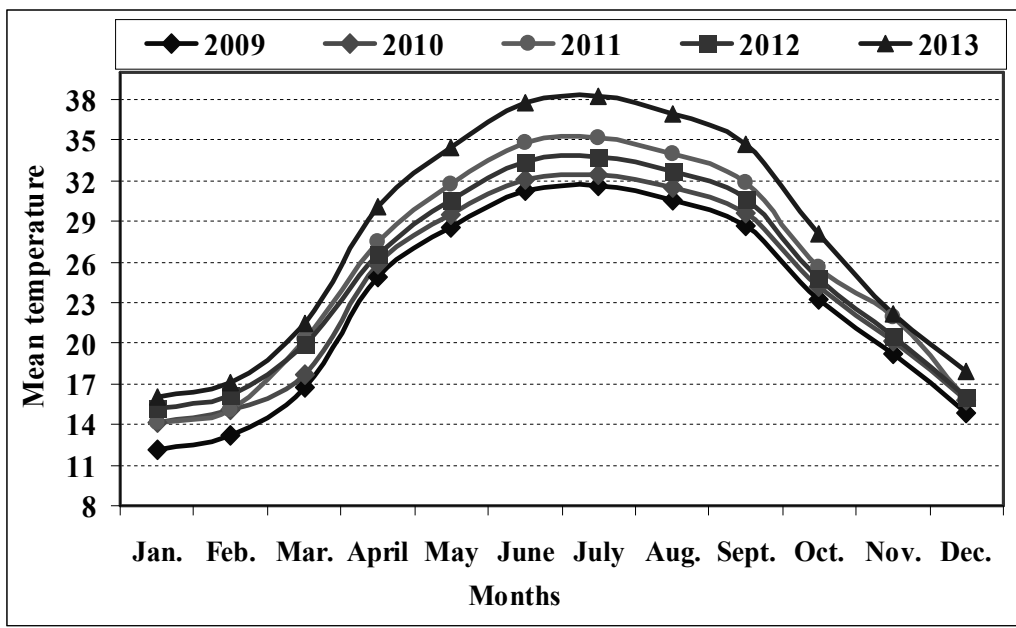

Fig. 1. Means of monthly air temperature under climatic conditions at Esna district, Luxor Governorate during the period from 2009 to 2013 years.

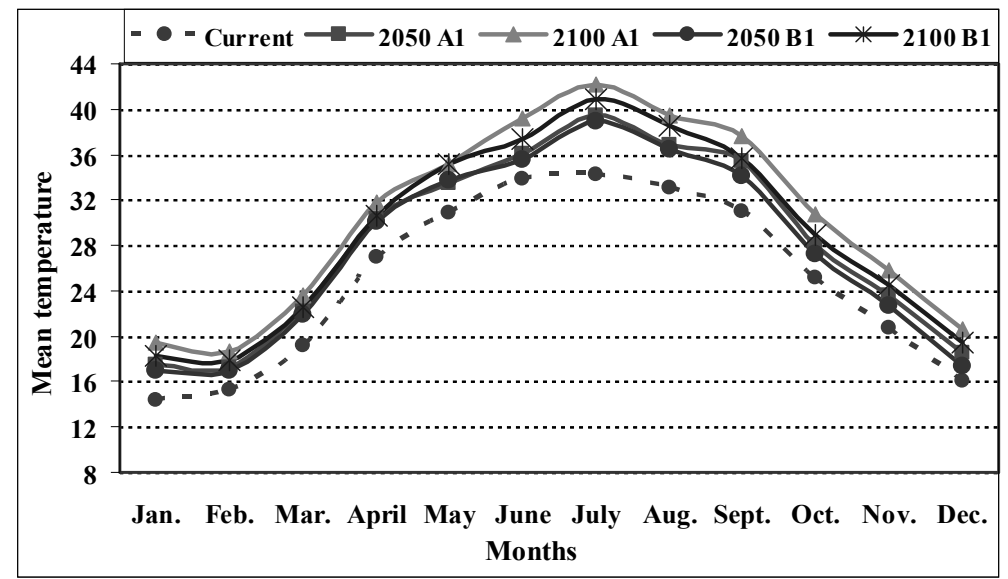

Fig. 2. Means of monthly air temperature under current and future climatic conditions for Esna district, Luxor Governorate.

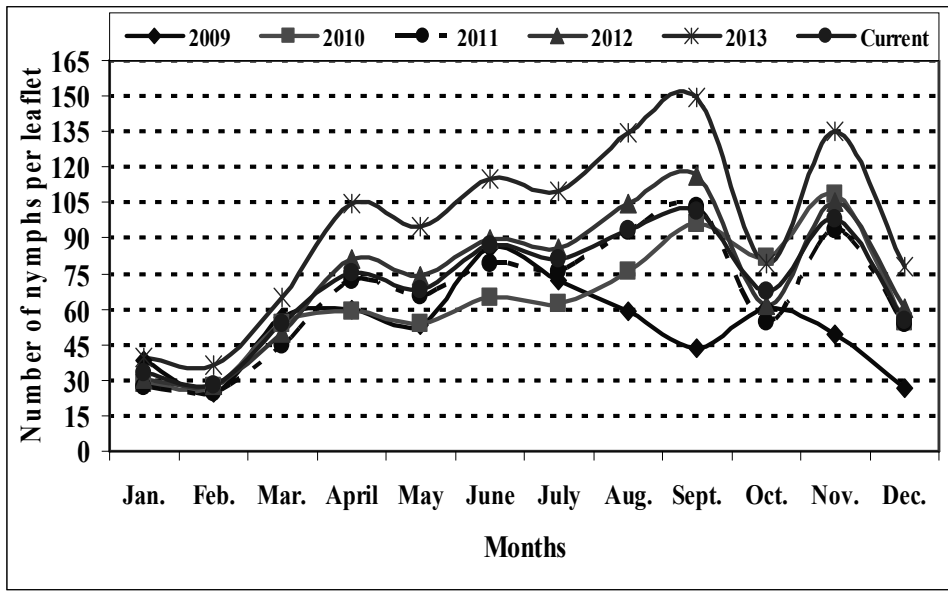

Fig. 3. Monthly mean number of nymphs of $P$. blanchardii on date palm leaflets at Esna district, Luxor Governorate during the period from 2009 to 2013 years and current data. 


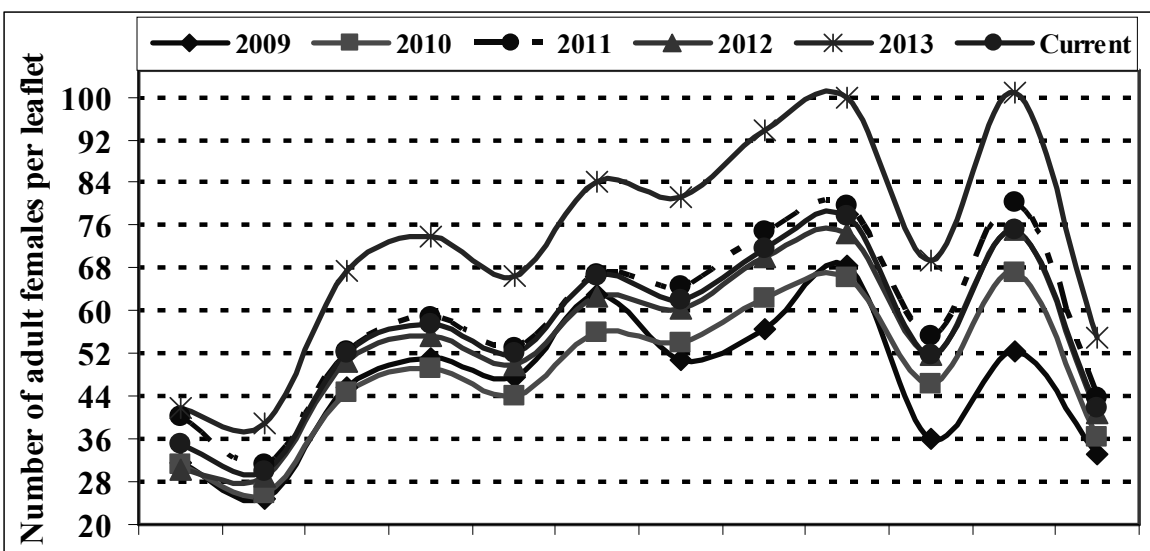

Jan. Feb. Mar. April May June July Aug. Sept. Oct. Nov. Dec.

Months

Fig. 4. Monthly mean number of adult females of $P$. blanchardii on date palm leaflets at Esna district, Luxor Governorate during the period from 2009 to 2013 years and current data.

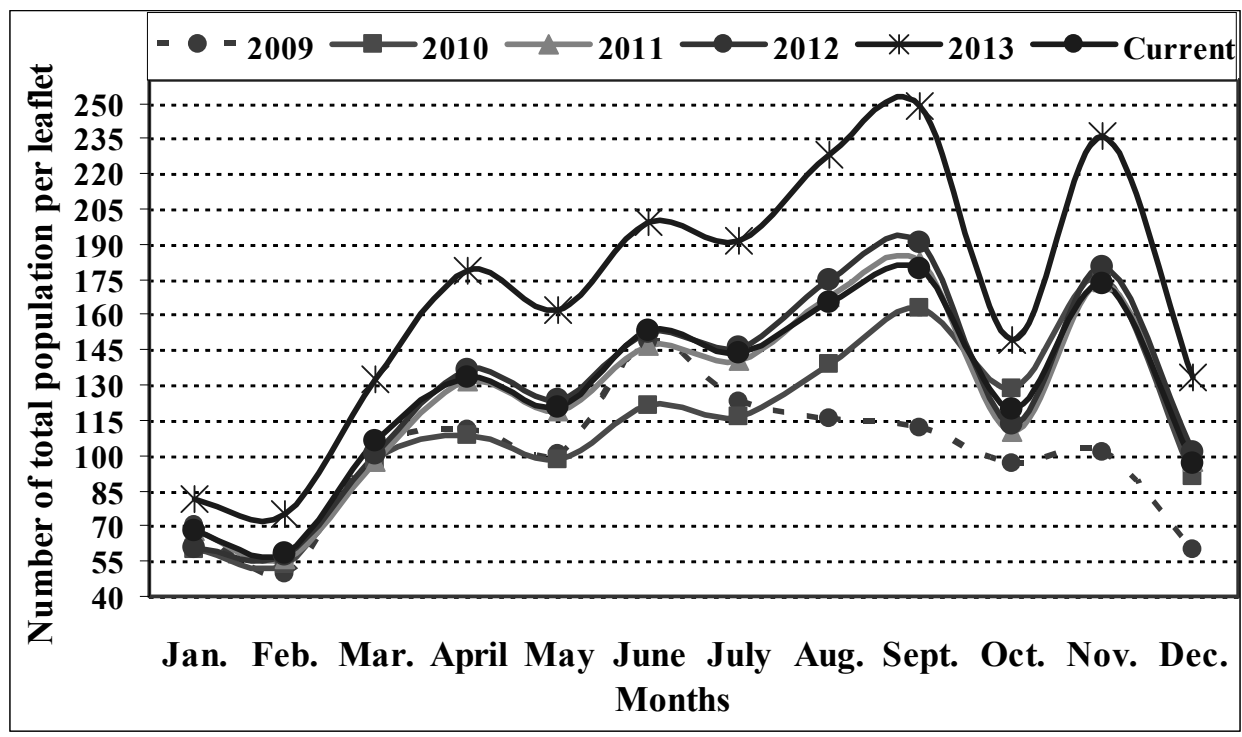

Fig. 5. Monthly mean number of total population of $P$. blanchardii on date palm leaflets at Esna district, Luxor Governorate during the period from 2009 to 2013 years and current data. 

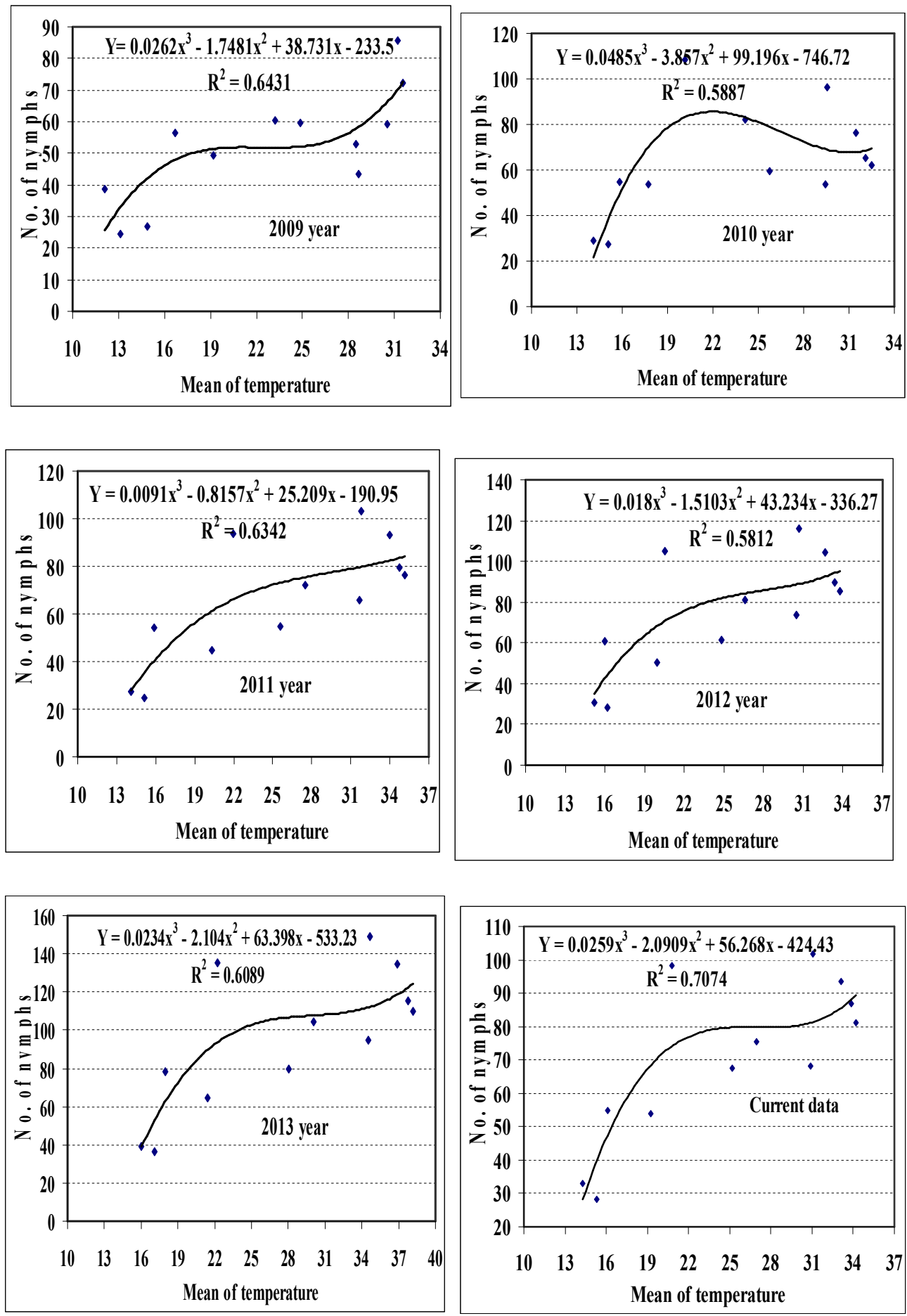

Fig. 6. Relationship between mean of temperature and nymph numbers of $P$. blanchardii during the period from 2009 to 2013 years and current data. 

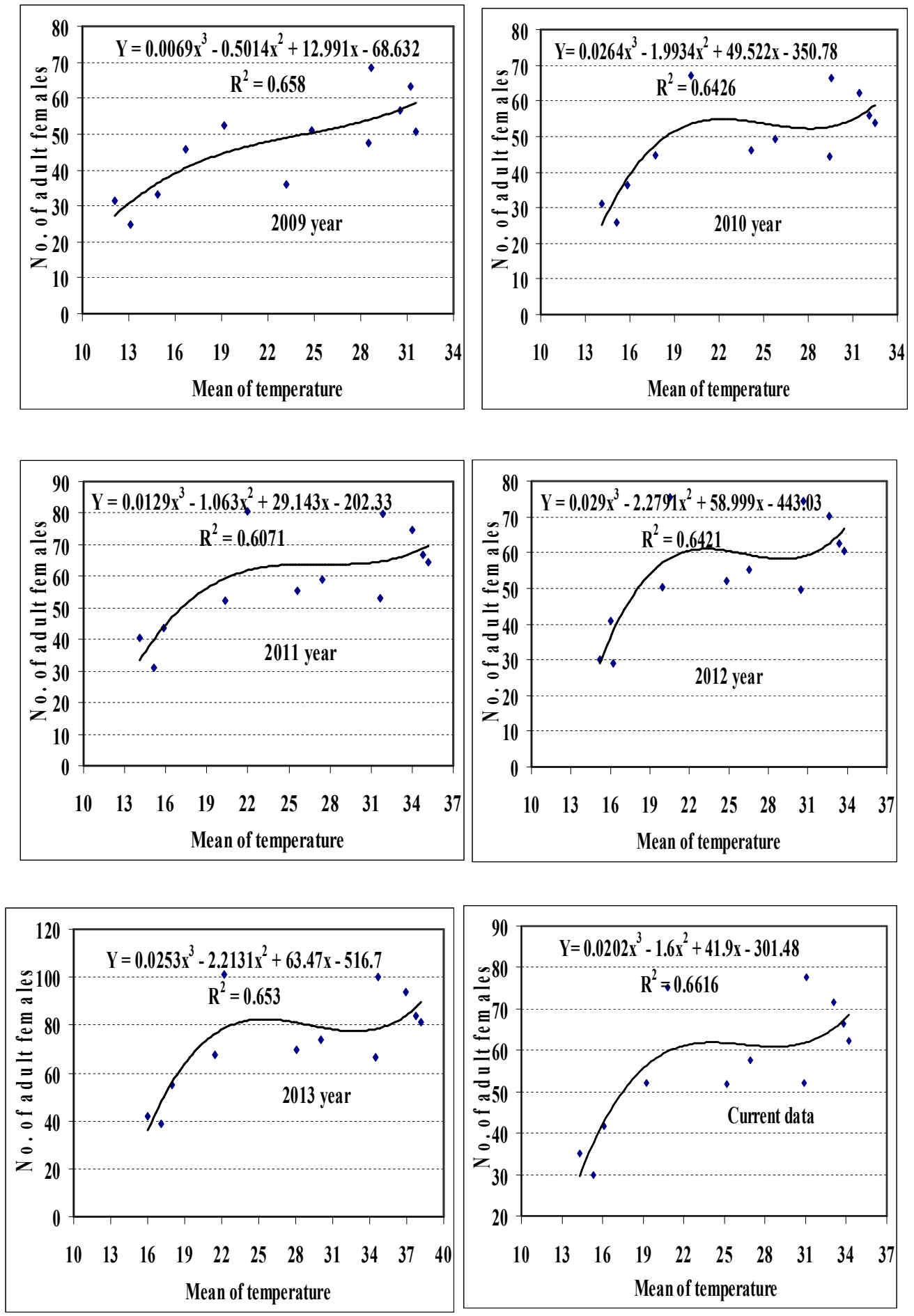

Fig. 7. Relationship between mean of temperature and adult females' numbers of $P$. blanchardii during the period from 2009 to 2013 years and current data. 

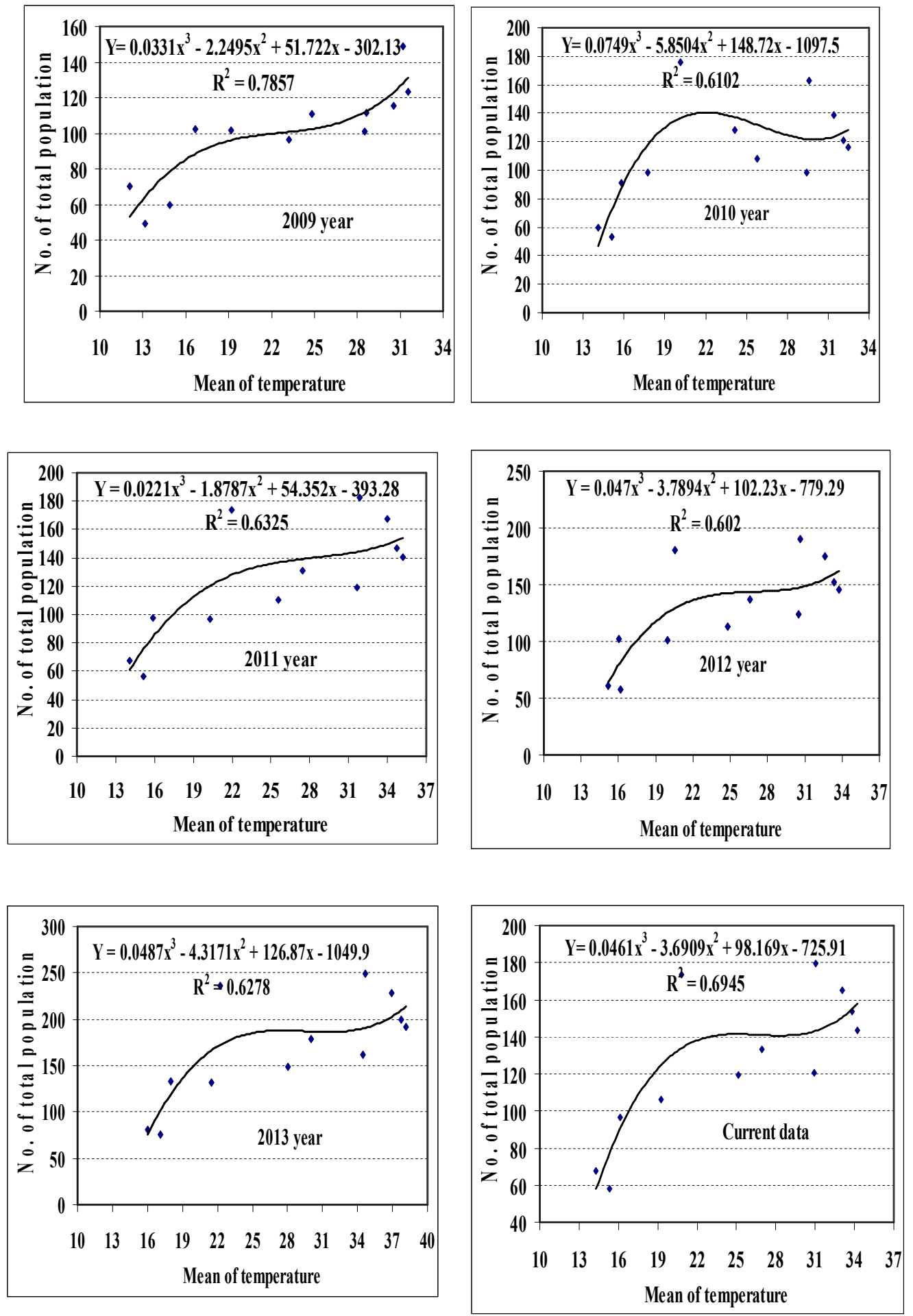

Fig. 8. Relationship between mean of temperature and total population numbers of $P$. blanchardii during the period from 2009 to 2013 years and current data. 
246 CLIMATE CHANGE IMPACT ON POPULATION DENSITY OF PARLATORIA DATE SCALE INSECT, PARLATORIA BLANCHARDII INFESTING DATE PALM TREES IN LUXOR GOVERNORATE, EGYPT

Table 1. Monthly mean number of nymphs of $P$. blanchardii under current and future conditions at Esna district, Luxor Governorate.

\begin{tabular}{|c|c|c|c|c|c|c|}
\hline \multirow{2}{*}{ Stage } & \multirow{2}{*}{ Months } & \multirow{2}{*}{ Current } & \multicolumn{2}{|c|}{ A1 Scenario } & \multicolumn{2}{|c|}{ B1 Scenario } \\
\hline & & & 2050 & 2100 & 2050 & 2100 \\
\hline \multirow{12}{*}{ 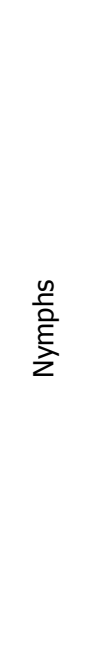 } & January & 32.9 & 58.6 & 69.8 & 54.7 & 63.5 \\
\hline & February & 28.2 & 57.0 & 65.9 & 54.5 & 61.1 \\
\hline & March & 54.0 & 77.9 & 79.3 & 77.0 & 78.1 \\
\hline & April & 75.4 & 81.4 & 83.3 & 81.1 & 81.7 \\
\hline & May & 68.3 & 87.9 & 94.6 & 88.5 & 95.1 \\
\hline & June & 87.0 & 100.5 & 128.4 & 97.2 & 109.9 \\
\hline & July & 81.3 & 131.7 & 172.9 & 125.6 & 150.1 \\
\hline & August & 93.5 & 106.2 & 131.2 & 102.6 & 120.5 \\
\hline & September & 101.6 & 96.2 & 112.2 & 90.1 & 97.6 \\
\hline & October & 67.7 & 80.4 & 81.9 & 80.3 & 80.5 \\
\hline & November & 98.3 & 79.4 & 80.3 & 78.4 & 80.0 \\
\hline & December & 54.9 & 65.1 & 73.7 & 58.2 & 69.3 \\
\hline & rage & 70.3 & 85.2 & 97.8 & 82.3 & 90.6 \\
\hline \multicolumn{3}{|c|}{$P \leq 0.05$} & $*$ & $*$ & $*$ & $*$ \\
\hline \multicolumn{3}{|c|}{ Increase } & 21.23 & 39.19 & 17.20 & 28.99 \\
\hline
\end{tabular}

Table 2. Monthly mean number of adult females of $P$. blanchardii under current and future conditions at Esna district, Luxor Governorate.

\begin{tabular}{|c|c|c|c|c|c|c|}
\hline \multirow{2}{*}{ Stage } & \multirow{2}{*}{ Months } & \multirow{2}{*}{ Current } & \multicolumn{2}{|c|}{ A1 Scenario } & \multicolumn{2}{|c|}{ B1 Scenario } \\
\hline & & & 2050 & 2100 & 2050 & 2100 \\
\hline \multirow{12}{*}{ 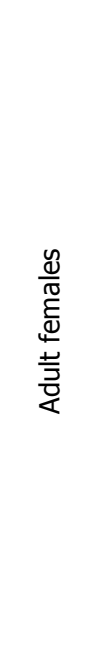 } & January & 35.0 & 49.9 & 57.0 & 47.4 & 53.1 \\
\hline & February & 30.0 & 48.9 & 54.6 & 47.3 & 51.6 \\
\hline & March & 52.1 & 61.3 & 61.7 & 60.9 & 61.4 \\
\hline & April & 57.7 & 61.1 & 62.5 & 60.9 & 61.3 \\
\hline & May & 52.2 & 66.1 & 71.5 & 66.6 & 71.9 \\
\hline & June & 66.5 & 76.3 & 99.1 & 73.6 & 84.0 \\
\hline & July & 62.2 & 101.8 & 135.4 & 96.8 & 116.8 \\
\hline & August & 71.5 & 81.0 & 101.4 & 78.0 & 92.6 \\
\hline & September & 77.8 & 72.8 & 85.9 & 67.8 & 74.0 \\
\hline & October & 51.8 & 60.7 & 61.4 & 60.9 & 60.7 \\
\hline & November & 75.2 & 61.7 & 61.4 & 61.5 & 61.7 \\
\hline & December & 41.8 & 54.1 & 59.2 & 49.7 & 56.7 \\
\hline & rage & 56.1 & 66.3 & 75.9 & 64.3 & 70.5 \\
\hline \multicolumn{3}{|c|}{$P \leq 0.05$} & $*$ & $*$ & $*$ & $*$ \\
\hline \multicolumn{3}{|c|}{ Increase } & 18.10 & 35.22 & 14.49 & 25.53 \\
\hline
\end{tabular}


Table 3. Monthly mean number of total population of $P$. blanchardii under current and future conditions at Esna district, Luxor Governorate.

\begin{tabular}{|c|c|c|c|c|c|c|}
\hline \multirow{2}{*}{ Stage } & \multirow{2}{*}{ Months } & \multirow{2}{*}{ Current } & \multicolumn{2}{|c|}{ A1 Scenario } & \multicolumn{2}{|c|}{ B1 Scenario } \\
\hline & & & 2050 & 2100 & 2050 & 2100 \\
\hline \multirow{12}{*}{$\begin{array}{l}0 \\
0 \\
\frac{0}{0} \\
\frac{\pi}{2} \\
00 \\
\frac{0}{0} \\
\bar{\pi} \\
0 \\
0\end{array}$} & January & 67.9 & 108.5 & 126.7 & 102.1 & 116.7 \\
\hline & February & 58.2 & 105.9 & 120.5 & 101.8 & 112.7 \\
\hline & March & 106.1 & 139.3 & 141.1 & 137.9 & 139.5 \\
\hline & April & 133.1 & 142.5 & 145.8 & 142.1 & 143.0 \\
\hline & May & 120.5 & 154.0 & 166.1 & 155.0 & 167.1 \\
\hline & June & 153.5 & 176.8 & 227.6 & 170.8 & 194.0 \\
\hline & July & 143.4 & 233.5 & 308.4 & 222.4 & 266.9 \\
\hline & August & 165.1 & 187.2 & 232.6 & 180.6 & 213.2 \\
\hline & September & 179.4 & 169.1 & 198.1 & 157.9 & 171.6 \\
\hline & October & 119.4 & 141.1 & 143.3 & 141.3 & 141.2 \\
\hline & November & 173.5 & 141.1 & 141.7 & 140.0 & 141.7 \\
\hline & December & 96.7 & 119.2 & 132.9 & 107.9 & 126.1 \\
\hline \multicolumn{2}{|c|}{ Average } & 126.4 & 151.5 & 173.7 & 146.6 & 161.1 \\
\hline \multicolumn{3}{|c|}{$P \leq 0.05$} & $*$ & $*$ & $*$ & $*$ \\
\hline \multicolumn{3}{|c|}{ Increase } & 19.86 & 37.45 & 16.02 & 27.47 \\
\hline
\end{tabular}

\section{REFERENCES}

1. Abdel-Kareim, A.I. and S.S. Awadalla. 1998. Population dynamics of the date palm scale, Parlatoria blanchardi (Targioni- Tozzetti) (Homoptera: Diaspididae). J. Agric. Sci. Mansoura Univ., 23 (7): 3431-3441 pp.

2. Bale, J., G. Masters, I. Hodkinson, C. Awmack, T. Bezemer, V. Brown, J. Butterfield, A. Buse, J. Coulson and J. Farrar (2002): Herbivory in global climate change research: direct effects of rising temperature on insect herbivores. Global Change Biol. 8: 1-16 pp.

3. Blumberg, D. 2008. Date Palm Arthropod Pests and Their Management in Israel. Phytoparasitica 36(5): 411-448 pp.

4. Cannon, R. 1998. The implications of predicted climate change for insect pests in the UK, with emphasis on non-indigenous species. Glob. Chang. Biol. 4, 785-796 pp.

5. Dent, D. 1991.Insect Pest Management. C.A.B. International. 
6. El-Said, M.I. 2000. Survey of date palm insects in North Sinai with special reference to the ecology and biology of the species, Parlatoria blanchardii (Targioni- Tozzettii), supper family Coccoidea. M.Sc. Thesis, Fac. of Agric., Cairo Univ., 97 pp.

7. El-Sherif, S.I., E.A. Elwan and M.I.E. Abd-El-Razik. 2001. Ecological observations on the date palm parlatoria scale, Parlatoria blanchardii (Targioni- Tozzettii) (Hemiptera: Diaspididae) in north Sinai, Egypt. Second International Conference on Date Palms (Al-Ain, UAE, March 25-27).

8. Elwan, E.A. and M.I. El-Said. 2009. Biological studies on the Parlatoria date scale, Parlatoria blanchardii (Targioni- Tozzettii) under laboratory conditions. Arab J. Plant Prot., October. Vol. 27, special Issue (Supplement): A$45 \mathrm{pp}$.

9. Eraki, M.M. 1998. Ecological studies on some scale insects infesting date palm trees. Ph.D. Thesis, Fac. of Agric., Al-Azhar Univ., Egypt 127 pp.

10. Farag Hussain, A.E. 1996. Comparative study on distribution and seasonal abundance of date scale, Parlatoria blanchardii (Targioni- Tozzettii). Populations in Giza and Bahria Oases regions. Bull. Ent. Soc. Egypt., 74:54-60 pp.

11. Idder-Ighili, H., M.A. Idder, B. Doumandji-Mitiche, and H. Chenchouni. 2015. Modeling the effects of climate on date palm scale (Parlatoria blanchardl) population dynamics during different phenological stages of life history under hot arid conditions. Int. J. Biometeorol. 2015 Jan 20 (on lone abst., Epub ahead of print).

12. Intergovernmental Panel on Climate Change (IPCC): McCarthy, J.J., O.F. Canziani, N. A. Leary, D.J. Dokken and K.S. White, eds. Climate change. 2001. Impact, Adaptation and Vulnerability: Contribution of Working Group II to the Third Assessment Report of the IPCC. In Cambridge Univ. Press, Cambridge, UK, $1000 \mathrm{pp}$.

13. Intergovernmental Panel on Climate Change (IPCC): IPCC Guidelines for National Greenhouse Gas Inventories programme, edited by: Eggleston, H.S., L. Buendia, K. Miwa, T. Ngara and K. Tanabe 2006. The institute for Global Environmental Strategies (IGES), Hayama. http://www.ipcc-nggip.iges.or.jp/public/2006gl/vol4.html

14. Intergovernmental Panel on Climate Change (IPCC): Summary for Policymakers. In Parry, M.L., Canziani, O.F., Palutikof, J.P., van der Linden, P.J. \& Hanson, C.E., eds. Climate Change. 2007. Impacts, Adaptation and Vulnerability. Contribution of Working Group II to the Fourth Assessment Report of the Intergovernmental Panel on Climate Change, pp. 7-22. Cambridge University Press, Cambridge, UK, 2007. http://www.ipcc.ch/pdf/assessment-report/ar4/wg2/ar4-wg2-intro.pdf. 
15. Laudeho, Y. and C. Benassy. 1969. Contribution a letude del ecologie de Parlatoria blanchardii (Targioni-Tozzettii) on Adrar Mauritania. Fruits, 24: 273$287 \mathrm{pp}$.

16. Meehl, G., T. Stocker, W. Collins, P. Friedlingstein A. Gaye, S. Solomon, D. Qin, M. Manning, Z. Chen and M. Marquis. 2007. Climate Change. 2007. The Physical Science Basis. Contribution of Working group I to the Fourth Assessment Report of the Intergovernmental Panel on Climate Change. Cambridge University Press, Cambridge, UK and New York, NY, USA.

17. Menéndez, R. 2007. How are insects responding to global warming? Tijdschrift voor Entomologie, 150 (2): 355-365 pp.

18. Merrill, R., D. Gutie'rrez, O. Lewis, J. Gutie'rrez, S. Diez and R. Wilson. 2008. Combined effects of climate and biotic interactions on the elevational range of a phytophagous insect. J. Anim. Ecol. 77, 145-155 pp.

19. MSTATC 1980. A Microcomputer Program of the Design Management and Analysis of Agronomic Research Experiments. Michigan State Univ., USA.

20. Parmesan, C. 2007. Influences of species, latitudes and methodologies on estimates of phenological response to global warming. Glob. Chang. Biol. 13, 1860-1872 pp.

21. Samways, M. 2005. Insect Diversity Conservation. Cambridge University Press, Cambridge.

22. Salem, S.A. and M.K Hamdy. 1985. On the population dynamics of Ceroplastes floridensis Comst. On guava trees, in Egypt. Bull. Entomol. Soc. Egypt. 64:227$237 \mathrm{pp}$.

23. Walther, G.R., E. Post, P. Convey, A. Menzel, C. Parmesan and T.J.C. Beebee. 2002. Ecological responses to recent climate change. Nature. 416: 389-395 pp.

24. Woiwod, I. 1997. Detecting the effects of climate change on Lepidoptera. J. Insect Conserv. 1, 149-158 pp.

25. Youssef, A.E. 2002. Ecological studies on date palm scale insect, Parlatoria blanchardii (Targ.) on two date palm varieties at Kafr El-Sheikh Governorate. J. Agri. Sci., Mansoura (27): 1291-1299 pp.

26. Zalom, F., P. Goodell, L. Wilson, W. Barnett and W. Bentley. 1983. Degree-days: the calculation and use of heat unit in pest management. Division of Agricultural and Natural Resources, University of California, Davis, CA, USA. 10 pp. 


\title{
تأثير ظروف تغير المناخ الحالية والمستقبلية المتوقعة على الكثافة العددية لحشرة

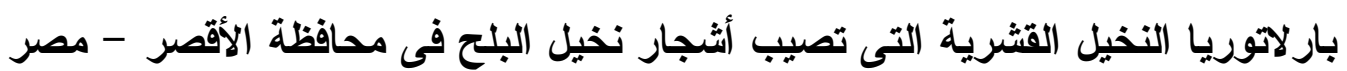

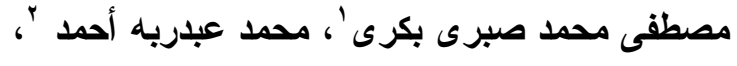

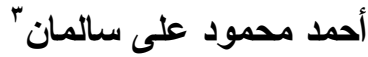 \\ 1- قسم بحوث الحشرات القشرية و البق الدقيقى- معهر بحوث وقاية النباتات - مركز البحوث

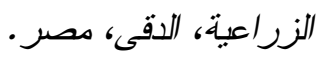 \\ r- المعدل المركزى للمناخ الزراعى، مركز البحوث الزراعية، الدقى، جيزة ، مصر.

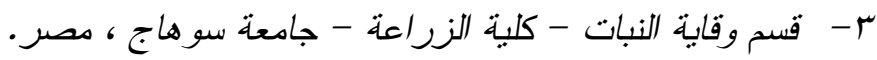

تعتبر حشرة بار لاتوريا النخيل القشرية من الآفات الخطيرة التى تصيب أثنجار نخيل الـــلح

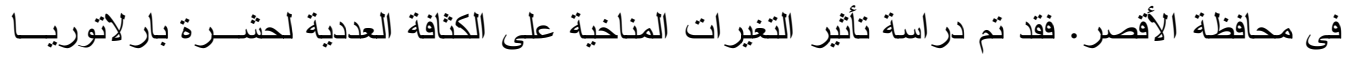

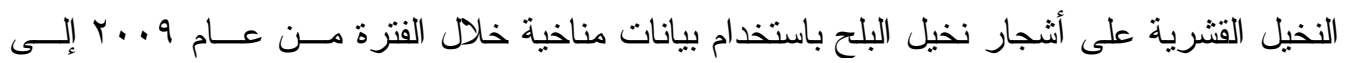

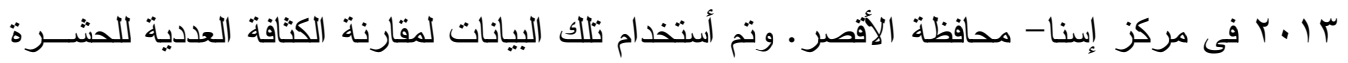

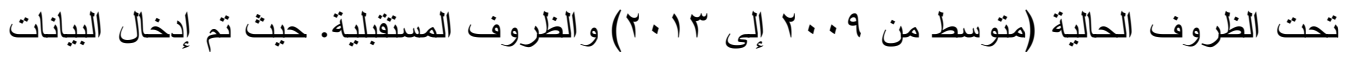

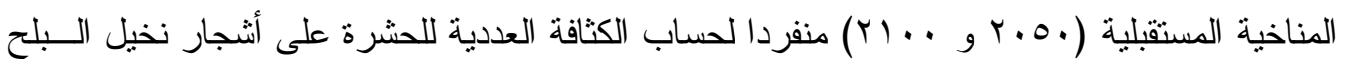

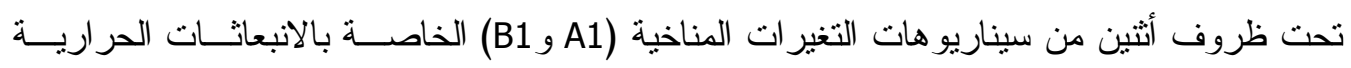

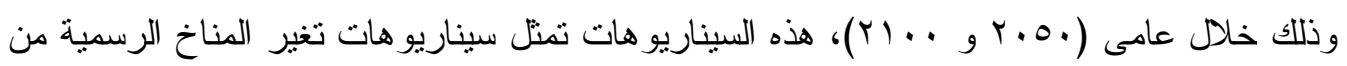
قبل الهيئة الحكومية الدولية لتغير المناخ (IPCC). و أظهرت النتائج إلى وجود من ثلاثة إلى أربع قمم لنشاط التعداد الكلى للحشرة خلاد العاد العام.

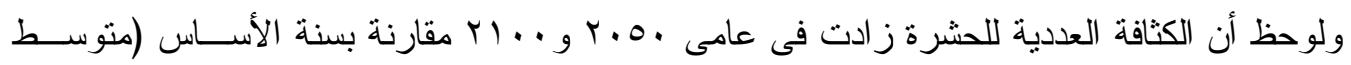

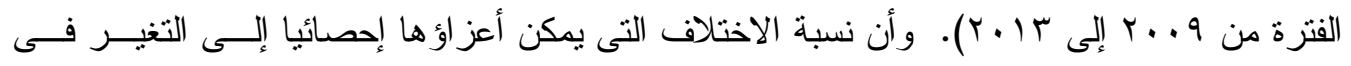

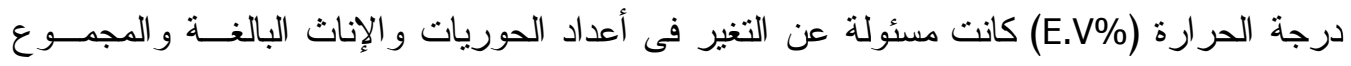

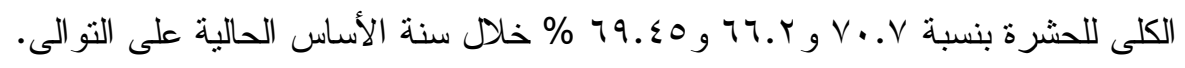

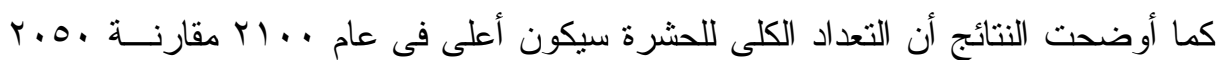

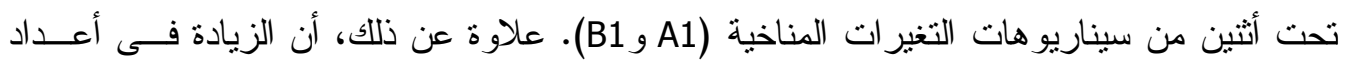

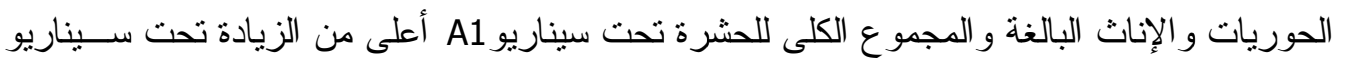

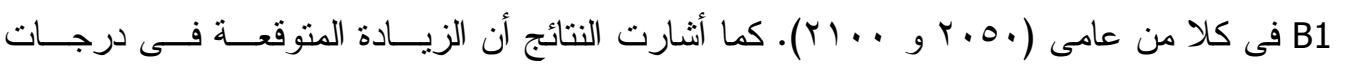

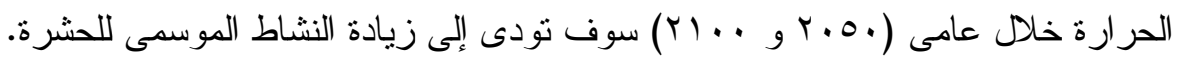

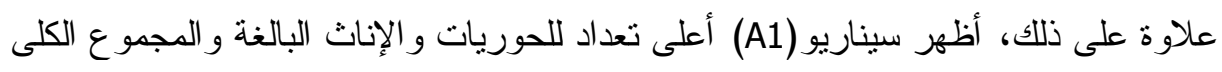

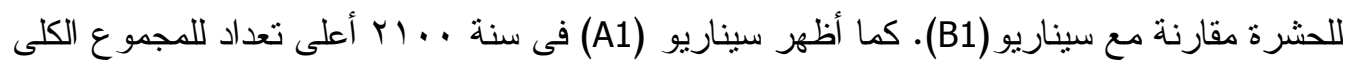

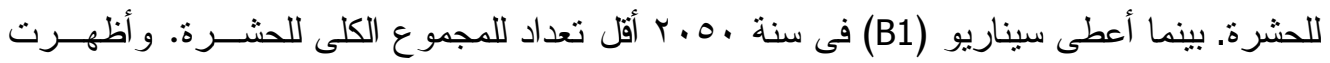

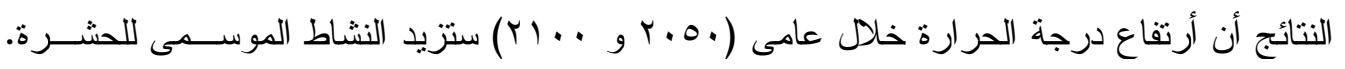
وعموما، فان زيادة الكثافة العددية للحشرة تعتمد على منطقة المناخ وسيناريو هات تغير الهير المناخ. 